\title{
Methodology to identify badly weathering limestone using geochemistry: case study on the Lower Globigerina Limestone of the Maltese islands
}

\author{
JoAnn Cassar ${ }^{1}$ \& Alfred J. Vella ${ }^{2}$ \\ ${ }^{1}$ Institute for Masonry and Construction Research, University of Malta, Msida MSD 06, Malta \\ (e-mail: joann.cassar@um.edu.mt) \\ ${ }^{2}$ Department of Chemistry, University of Malta, Msida MSD 06, Malta (e-mail: alfred.j.vella@um.edu.mt)
}

\begin{abstract}
T his paper proposes a new objective method to classify building limestone into types of varying durability working on samples that are visually identical in appearance. Geochemical data were obtained for 90 samples of the Lower Globigerina Limestone of the Maltese islands. Multivariate analyses, including cluster analysis, principal components analysis and discriminant analysis allowed the identification of variables $\mathrm{SiO}_{2}, \mathrm{Al}_{2} \mathrm{O}_{3}, \mathrm{~K}_{2} \mathrm{O}, \mathrm{TiO}_{2}, \mathrm{Fe}_{2} \mathrm{O}_{3}$ as indicators to distinguish between more durable 'franka' limestone and the less durable facies locally called 'soll'. This hypothesis was confirmed by differences in geochemical data from samples of both weathered and unweathered stone taken from abandoned quarry faces. In the less durable 'soll', $\mathrm{SiO}_{2}$ concentrations are $>3.4 \pm 0.3 \%, \quad \mathrm{Al}_{2} \mathrm{O}_{3}$ $>0.78 \pm 0.05 \%, \mathrm{~K}_{2} \mathrm{O}>0.13 \pm 0.01 \%, \mathrm{TiO}_{2}>0.06 \pm 0.002 \%$ and $\mathrm{Fe}_{2} \mathrm{O}_{3}>0.47 \pm 0.02 \%$. However, some overlap occurs between the two stone types for all five components, demarcating another stone type we designated as 'intermediate'. The geochemical differences are reflected in mineralogical data and in acid-insoluble residues. This geochemical method is simple and innovative. It can be used to identify newly extracted limestone for use in building and also for replacement of deteriorated stones in old buildings.
\end{abstract}

Keywords: durability, geochemistry, laboratory studies, limestone. weathering

\section{Introduction}

The Globigerina Limestone of the Maltese islands forms part of the large family of Oligo-Miocene 'soft limestones' diffused widely in the Mediterranean basin. This formation has provided the main building material of the Maltese islands from prehistoric times to date, and was, in the past, exported to all parts of the Mediterranean as well as to the UK.

The Globigerina Limestone, when used as a building stone, is locally referred to as 'franka' (or freestone). Stone that does not weather well is called 'soll' (or 'sol'). Various nineteenth and twentieth century publications referred to Maltese building stone which varied in durability. The less durable type of stone has been

Quarterly Journal of Engineering Geology and Hydrogeology, 36, 85-96 referred to as a stone 'that will not stand exposure' (Murray 1890) or that 'weather(s) rather badly' (Galea 1915). The 'franka' stone withstands exposure well, forming a resistant surface, whereas the 'soll' stone deteriorates and powders away easily, often showing varying degrees of alveolar (or honeycomb) weathering, losing much of its original thickness in the process (Fig. 1).

During the 1980s and 1990s, research was carried out sporadically aimed at establishing measurable variations in physical and/or mechanical properties between the durable 'franka' and the less durable 'soll' limestone. This led to some interesting conclusions (Fitzner et al. 1996; Cassar 2002). Studies carried out to date show that, compared to the 'franka' stone, 'soll' appears to have a lower overall porosity and a higher proportion of small pores; further work in this respect is currently being planned. Other studies, seeking geochemical differences in Lower Globigerina Limestone strata, were carried out on a limited number of samples obtained from fresh and weathered quarry faces. This work has now been expanded into a systematic geochemical study which includes a large number of samples that are identical in hand specimens, with the aim of establishing a reliable method to differentiate between the more and less durable types of building limestone.

The search for a method to predict the durability of building stone is centuries old. The durability of a particular stone depends on its intrinsic properties and on the aggressiveness of its environment. In many countries, the choice of stone is based on traditional use with no real testing. However, testing procedures currently in use are many and varied; these include test methods established by the Building Research Establishment (BRE), as well as international tests such as ASTM, DIN and AFNOR (Harrison 2001). European Standards, in particular non-destructive tests, are also currently being compiled. Presently available durability tests can be divided into two general categories: indirect measurements and direct tests. The first group include measurements of porosity, saturation coefficient, porosimetry and capillarity; an improved indication of durability is sometimes achieved by combining two of these properties (BRE 1983). Direct tests include frost tests and salt (sodium or magnesium sulphate) crystallization tests. Where the main cause of limestone decay is 


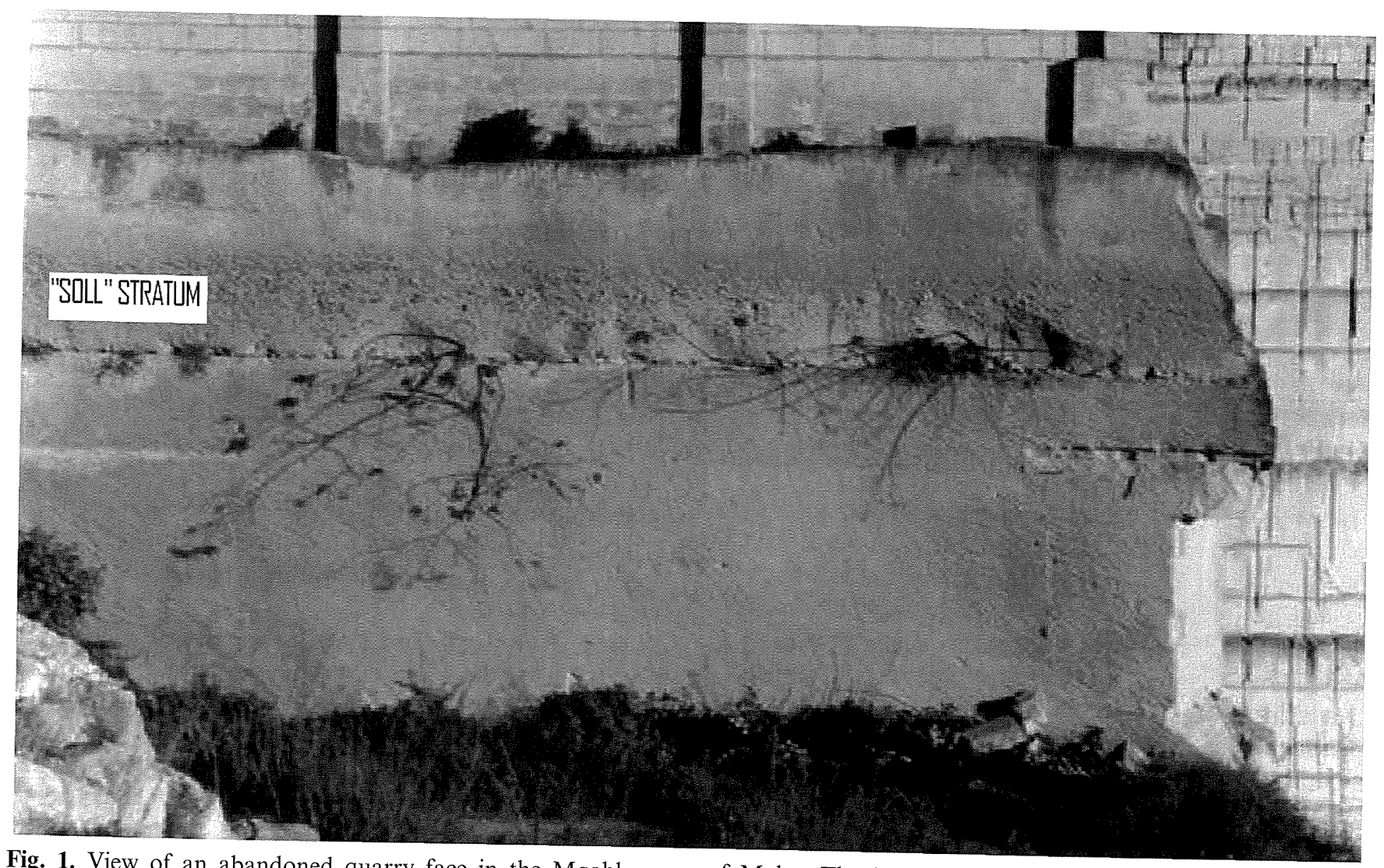

Fig. 1. View of an abandoned quarry face in the Mqabba area of Malta. The 'soll' stone is seen as a stratum with alveolar (honeycomb) weathering, whereas the 'franka' stone shows a sound surface.

considered to be salt damage, the salt crystallization test is considered to be the best single test for assessing durability (Honeyborne 1998). However, results of the salt crystallization test are best evaluated in conjunction with results obtained from other indirect test methods, such as porosity and water absorption tests, as well as performance of the stone in existing buildings (BRE 1999). On the other hand, chemical composition is generally regarded as not being useful in durability assessment (BRE 1983). Even in the case of Maltese Globigerina Limestone, testing carried out some years ago on a limited number of samples concluded that no correlation between mineral composition and stone quality could be found (Fitzner et al. 1996). However, the present research, consisting of a systematic geochemical study of a large number of samples, has in fact concluded that, in the case of the Globigerina Limestone of the Maltese islands, chemical composition can be used to predict durability.

\section{Geological context}

The Maltese islands lie on the southern end of the Pelagian shelf, $93 \mathrm{~km}$ due south of the Ragusa Peninsula of Sicily. The total exposed surface area is $316 \mathrm{~km}^{2}$. The islands and the surrounding submerged platform are characterized by Mesozoic sediments ranging from pure carbonates to carbonate marls, formed in shallow waters $(0-150 \mathrm{~m})$ on a stable near-horizontal platform. This region has seen continued carbonate sedimentation since the Triassic. The outcropping succession is OligoMiocene and is made up of a series of limestones and associated marls and, more rarely, dolomitic limestones and dolomites, as well as sporadic Quaternary deposits. The Maltese sequence resembles the mid-Tertiary limestones of the Ragusa region of Sicily and of North Africa. Malta was apparently part of a Mesozoic and mid-Tertiary carbonate platform, extending from southern Sicily to North Africa, with Malta being situated toward the leading edge of the African plate (Pedley 1978).

There are five main formations in the Maltese islands: Upper Coralline Limestone (46-104 m), Greensand $(0-11 \mathrm{~m})$, Blue Clay $(15-75 \mathrm{~m})$, Globigerina Limestone $(23-144 \mathrm{~m})$ and Lower Coralline Limestone (>48 m) (Oil Exploration Directorate 1993). The Globigerina Limestone formation outcrops mainly in the central and southern parts of the main island of Malta, and in the western part of the smaller island of Gozo. Lithologically this formation consists of fine-grained limestones, almost wholly composed of the tests of globigerinid planktonic foraminifera. This formation is stratified into thick beds at outcrop. Sections where bioturbation is concentrated occur frequently. This formation is divided into three members by two continuous phosphorite 


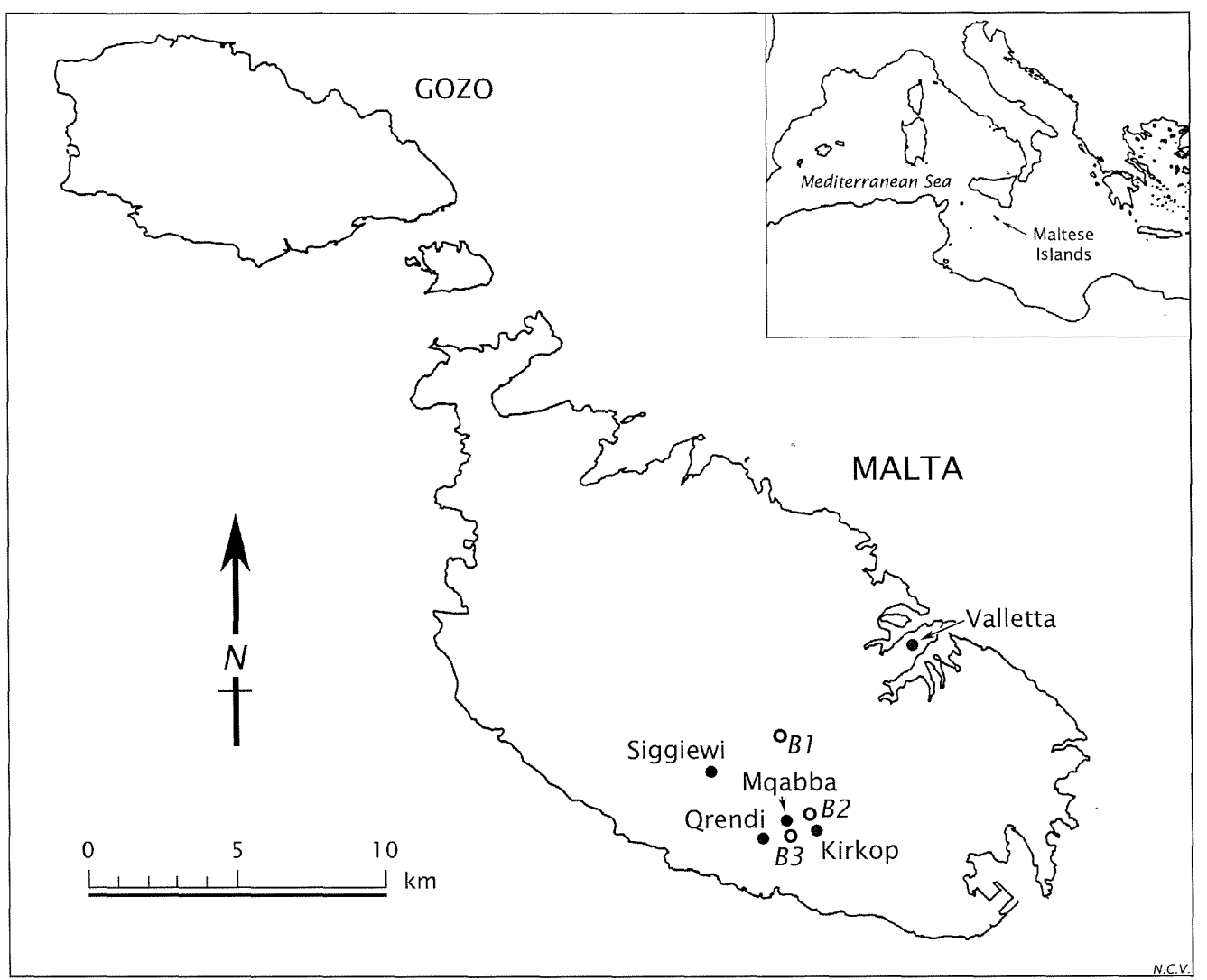

Fig. 2. Map of the Maltese islands, showing the main quarry area centred around the villages of Mqabba, Qrendi, Kirkop and Siggiewi, as well as the boreholes samples (B1, B2, B3).

horizons, which are usually about $50 \mathrm{~cm}$ thick. The three members thus formed are, from the top downwards, the Upper, Middle and Lower Globigerina Limestone. The Lower Globigerina Limestone member is composed primarily of massive, pale cream to yellow, globigerinid biomicritic limestones and partially marly limestones. Macrofossils are abundant only locally and consist of molluscs, echinoderms, bryozoa and various pteropod species. It often also contains trace fossils.

Quarries of various sizes are located in this member in two principal islands of Malta and Gozo. Limestone is extracted entirely by open pit methods. Globigerina Limestone is cut and sold as building blocks and slabs. The Maltese stone worker generally acknowledges that seams of badly weathering Lower Globigerina Limestone, or 'soll', occur from time to time in otherwise good quality strata. It is the 'franka' and 'soll' facies that are difficult to identify in the field that are the subjects of this study.

\section{Materials and methods}

Samples were cut from cores obtained from boreholes (B1, B2, B3) located in or near the main quarry area of the Maltese islands, around the villages of Mqabba, Qrendi, Kirkop and Siggiewi (Fig. 2). The co-ordinates of the three boreholes are as follows: B1 - NG
51353.00E 69563.00 N; B2 - NG 52254.00E $66497.00 \mathrm{~N}$; B3 - NG 53152.00E $67495.00 \mathrm{~N}$.

$\mathrm{B} 1$ and $\mathrm{B} 2$ were obtained from outcrops lying close to the excavated area, whereas B3 was extracted from the bottom of an active quarry (Tar-Robba, at Mqabba) starting at a depth of $14 \mathrm{~m}$. The cores were approximately $74 \mathrm{~mm}$ in diameter and included mainly the Lower Globigerina Limestone member. The lengths recovered were of $44.65 \mathrm{~m}, 47.50 \mathrm{~m}$ and $28.30 \mathrm{~m}$ respectively. In addition, all three cores included some of the Lower Coralline Limestone Formation, ranging from $3.2 \mathrm{~m}$ for B3, to $5.35 \mathrm{~m}$ for $\mathrm{B} 1$, to $18.8 \mathrm{~m}$ for $\mathrm{B} 2$. Core $\mathrm{B} 2$ also contained $13.5 \mathrm{~m}$ of the Middle Globigerina Limestone member. Some 109 samples were taken from the Lower Globigerina Limestone member, one sample being obtained every $1 \mathrm{~m}$. These were analysed geochemically and mineralogically (Cassar 1999). In addition, thin section studies were carried out on 32 of these samples. A further 23 samples of Lower Globigerina Limestone were taken from two weathered faces of the same quarry mentioned above. All these samples showed varying grades of deterioration.

Chemical analyses for bulk chemical composition were carried out by X-ray fluorescence (XRF); the standard measuring operation comprised eight major components $\left(\mathrm{Al}_{2} \mathrm{O}_{3}, \mathrm{SiO}_{2}, \mathrm{P}_{2} \mathrm{O}_{5}, \mathrm{~K}_{2} \mathrm{O}, \mathrm{CaO}, \mathrm{TiO}_{2}, \mathrm{MnO}\right.$ and $\mathrm{Fe}_{2} \mathrm{O}_{3}$ ). Analyses of $\mathrm{Na}_{2} \mathrm{O}$ and $\mathrm{MgO}$ were carried 
Table 1. Geochemical results for 90 Lower Globigerina Limestone samples from boreholes.

\begin{tabular}{|c|c|c|c|c|c|c|c|c|c|c|}
\hline & $\mathrm{Na}_{2} \mathrm{O} \%$ & $\mathrm{MgO} \%$ & $\mathrm{Al}_{2} \mathrm{O}_{3} \%$ & $\mathrm{SiO}_{2} \%$ & $\mathrm{~K}_{2} \mathrm{O} \%$ & $\mathrm{P}_{2} \mathrm{O}_{5} \%$ & $\mathrm{CaO} \%$ & $\mathrm{TiO}_{2} \%$ & $\mathrm{MnO} \%$ & $\mathrm{Fe}_{2} \mathrm{O}_{3} \%$ \\
\hline Mean & 0.040 & 0.71 & 1.18 & 4.0 & 0.19 & 0.21 & 49.71 & 0.080 & 0.010 & 0.66 \\
\hline Standard deviation & 0.030 & 0.16 & 0.57 & 1.75 & 0.10 & 0.10 & 1.98 & 0.040 & 0.00 & 0.32 \\
\hline Min-max & $0.0-0.19$ & $0.32-1.08$ & $0.40-2.90$ & $1.8-9.4$ & $0.040-0.47$ & $0.10-0.71$ & $44.49-52.87$ & $0.030-0.20$ & $0.0-0.020$ & $0.26-1.64$ \\
\hline Confidence level $(95.0 \%)$ & 0.006 & 0.033 & 0.120 & 0.367 & 0.021 & 0.020 & 0.416 & 0.008 & 0.001 & 0.068 \\
\hline
\end{tabular}

out by atomic absorption spectrometry (AAS). Mineralogical identification of bulk samples and clay fractions was conducted by X-ray diffraction (XRD). Determination of acid-insoluble residue was performed indirectly from calcimetry.

For XRF analyses, standards and samples were prepared as pressed powder pellets (briquettes). Approximately $10 \mathrm{~g}$ of each sample were first crushed and ground, taking care to thoroughly homogenize the powder; $c .4 \mathrm{~g}$ of the ground material were used to prepare boric acid pellets, $50 \mathrm{~mm}$ in diameter. For each sample, one pellet was prepared; each was run through the XRF instrument several times to verify the precision of the results. Elemental concentrations in these samples, as well as the associated accuracy of the results, were obtained by setting up calibration curves using natural rock standards as certified reference material (CRM).

The geochemical data obtained from XRF analyses resulted in a very large dataset containing a substantial amount of information on the composition of the samples under investigation. Multivariate statistical methods were used for the treatment of geochemical data generated. Data reduction was carried out principally by cluster analysis, a name which generically describes a very large assortment of numerical classification techniques, where the number of groups is not known in advance (Davis 1986). This statistical method is often used in geology and geochemistry to reveal any underlying groupings. Numerical classification methods are meant to provide classifications that are objective and stable. 'Ideal types' or 'markers' were added to the data to allow for an interpretation of the clusters obtained. Principal components analysis (PCA) was later also carried out on the geochemical dataset. Both methods allowed for the samples to be organized into 'groups'. The information provided by PCA was used to verify whether the classification based on cluster analysis was in fact 'natural' or 'imposed', depending on whether the groups produced by both methods agreed. Multivariate analysis of variance (MANOVA) was also performed on the data pertaining to the groups isolated by cluster analysis. The relationship between the groups of variables from different clusters was compared in order to estimate the probability that the relation between variables is a chance occurrence. This probability is expressed in terms of $p$-levels. The smaller the p-level, the lesser the probability that the relationship is fortuitous. Discriminant analysis (DA) was used as a final verification of the results obtained. This served to estimate the misclassification of the method.

\section{Results and discussion}

The set of all geochemical results obtained can be expressed as a $109 \times 10$ data matrix which contains the values for ten variables, being the major elements analysed, for the 109 samples. Visual examination of hand specimens showed that 19 of the samples had colour and/or textural differences which set them apart from 'normal-looking' Lower Globigerina Limestone, which is a pale cream or yellow, fine-grained limestone with no marks or blemishes. It was therefore decided to proceed with studies only on the 90 samples that visually appeared to be identical (Cassar 1999). Table 1 gives geochemical data for these samples.

Cluster analysis was chosen as the method most likely to identify, if possible, the 'soll' samples within the dataset available, and hence to establish the composition of this limestone facies. Many authors sustain that classification methods work better if a large number of variables are utilized. Baxter \& Jackson (2001) quote various papers which support the 'more is better' view (Sneath \& Sokal 1973; Harbottle 1976; Pollard 1986; Glascock 1992). Other authors, however, dismiss the 'more is better' view, and retain that inclusion of too many variables that are neither informative nor structure-carrying can, in fact, obscure the visualization of real patterns. Thus, it has been suggested that only those variables that are believed to help discriminate clustering in the data should be selected for the analysis, as the addition of only one or two irrelevant variables can dramatically interfere with cluster recovery (Milligan 1996). Baxter \& Jackson (2001) support this, also quoting other authors who hold the view that many situations occur where using a sub-set of the measured variables is better (Fowlkes et al. 1988; Krzanowski 1988). Our work has led us to adopt this position.

Correlation matrices were drawn up to determine the sub-set of 'useful' geochemical variables for uncovering presumed groups in the data. The available raw data were initially converted into open data by being transformed into ratios. Already available $\mathrm{MgO}$ values were 
USING GEOCHEMISTRY TO IDENTIFY WEATHERED LIMESTONE

Table 2. Spearman's rank order correlations on ratios ( $\mathrm{MgO}$ as denominator) for 90 Lower Globigerina Limestone samples.

\begin{tabular}{lcccccccc} 
& $\mathrm{Na}_{2} \mathrm{O}$ & $\mathrm{Al}_{2} \mathrm{O}_{3}$ & $\mathrm{SiO}_{2}$ & $\mathrm{~K}_{2} \mathrm{O}$ & $\mathrm{P}_{2} \mathrm{O}_{5}$ & $\mathrm{CaO}$ & $\mathrm{TiO}_{2}$ & $\mathrm{MnO}^{2} \mathrm{Fe}_{2} \mathrm{O}_{3}$ \\
\hline $\mathrm{Na}_{2} \mathrm{O}$ & 1 & & & & & & & \\
$\mathrm{Al}_{2} \mathrm{O}_{3}$ & 0.5447 & 1 & & & & & \\
$\mathrm{SiO}_{2}$ & 0.5907 & 0.9438 & 1 & & & & \\
$\mathrm{~K}_{2} \mathrm{O}$ & 0.5865 & 0.9336 & 0.9111 & 1 & & & \\
$\mathrm{P}_{2} \mathrm{O}_{5}$ & 0.2647 & 0.0471 & 0.0917 & 0.0553 & 1 & 1 & 1 \\
$\mathrm{CaO}$ & -0.425 & -0.426 & -0.392 & -0.517 & 0.0705 & -0.293 & 0.2003 & 1 \\
$\mathrm{TiO}_{2}$ & 0.5089 & 0.9353 & 0.9499 & 0.893 & 0.0118 & -0.31 & 0.8429 & 0.4267 \\
$\mathrm{MnO}^{\mathrm{Fe}} \mathrm{O}_{3}$ & 0.1944 & 0.2489 & 0.2085 & 0.3672 & 0.0996 & -0.5 & 1 \\
\hline
\end{tabular}

chosen as the denominator, as this was found to be a minor component of the system, and was only weakly correlated to all the other components. This variable was also expected to be independent of the geological process being investigated, which is thought to centre primarily on the non-carbonate residue of the limestone samples. Choosing a variable which is independent of both the major 'diluting' components and the geological process being investigated as the denominator attempts to reduce the situation to a geological, rather than a statistical problem (Swan \& Sandilands 1995).

The available geochemical data were considered to be non-parametric, and therefore Spearman's rank correlation coefficient was used to draw up the correlation matrix (Cassar 1999). When non-parametric statistical tests are used, no assumptions about the form of the parent distribution are required (Davis 1986). The resulting correlation matrix is given in Table 2. High correlations were obtained for $\mathrm{SiO}_{2} / \mathrm{Al}_{2} \mathrm{O}_{3}, \mathrm{SiO}_{2} / \mathrm{TiO}_{2}$, $\mathrm{Al}_{2} \mathrm{O}_{3} / \mathrm{K}_{2} \mathrm{O}, \mathrm{Al}_{2} \mathrm{O}_{3} / \mathrm{TiO}_{2}, \quad \mathrm{SiO}_{2} / \mathrm{K}_{2} \mathrm{O}, \mathrm{K}_{2} \mathrm{O} / \mathrm{Fe}_{2} \mathrm{O}_{3}$, and $\mathrm{Al}_{2} \mathrm{O}_{3} / \mathrm{Fe}_{2} \mathrm{O}_{3}(>0.91)$. For $\mathrm{K}_{2} \mathrm{O} / \mathrm{TiO}_{2}, \mathrm{SiO}_{2} / \mathrm{Fe}_{2} \mathrm{O}_{3}$ and $\mathrm{TiO}_{2} / \mathrm{Fe}_{2} \mathrm{O}_{3}$ the correlations were also high at $>0.84$ (Cassar 1999). Thus the five variables chosen for the ensuing statistical analyses were $\mathrm{SiO}_{2}, \mathrm{Al}_{2} \mathrm{O}_{3}, \mathrm{TiO}_{2}, \mathrm{~K}_{2} \mathrm{O}$ and $\mathrm{Fe}_{2} \mathrm{O}_{3}$. These variables were incidentally also among those which previous workers had identified as possible indicators for the identification of 'soll' samples (Vella et al. 1997).

Cluster analysis was carried out using a variety of clustering techniques. The selection of the method to be used is the crux of the entire clustering procedure. It is important that the method selected must be suitable to reveal the type of clustering expected in the data. However, there are very few recommendations or guidelines to go by. Different clustering techniques may find different types of cluster structures. Most researchers who use clustering methods experiment with a variety of clustering techniques, and they choose the combination that yields the most satisfactory results with their data (Davis 1986). Here, a number of different linkage methods were utilized in an attempt to uncover the underlying structure (if any) in the dataset under examination. The different linkage methods used were (i) complete linkage (furthest neighbour method); (ii) unweighted average pair group linkage; (iii) weighted average pair group linkage; and (iv) Ward's method. To test whether cluster analysis could actually distinguish between 'franka' and 'soll' samples, purely on geochemical data, this method was first tried on 23 Lower Globigerina Limestone samples obtained from two abandoned quarry faces from the 'Tar-Robba' quarry (Cassar 1999). Initial inspection of the weathered quarry faces allowed visual determination of which of these samples were 'soll' and which 'franka': 12 'soll' and 11 'franka' samples were collected. In all cases, the exposed weathered surface was removed to a depth of between $10 \mathrm{~mm}$ and $20 \mathrm{~mm}$ before analyses were carried out. Table 3 gives geochemical data for the five variables used to cluster these 23 samples, as well as data for differentiated 'franka' and 'soll', while Table 4 provides the data for the borehole samples.

Cluster analysis confirmed that the method could classify limestones into 'soll' and 'franka' types utilizing solely geochemical data. Ward's method (Fig. 3) is given as an example (Cassar 1999). The phenon (dividing) line can be drawn at an early stage dividing the initial group of samples into two clusters, one containing 10 and the other 13 cases. The smaller cluster contains exclusively samples previously identified as 'franka', whereas the other cluster has 12 'soll' samples and one 'franka' sample as follows:

Cluster 1 ('franka'): E4, W6, W4, W12, W11, W5, W17, W10, E5, W3

Cluster 2 ('soll'): W15S, W13, W14S, W7S, E2S, E1S, W9S, W2S, E3S, E6S, W16S, W8S, W1S

It is to be noted that the only 'misplaced' sample is W13 which, in the field, was identified as 'franka', and was subsequently clustered with the 'soll' samples. However, this sample was obtained from the topmost part of the 'franka' layer, very close to the 'soll' facies.

Using complete linkage, weighted and unweighted average pair group methods, a five-case cluster is first isolated, which contains only 'soll' samples: E3S, E6S, W16S, W8S, W1S. In addition, all four methods yielded the same ten-member 'franka' group clustered together, distinct from the other 13 members. Figure 4 shows the clustering arrangement using the method of complete 
Table 3. Geochemical data for 23 samples from two weathered quarry faces in 'Tar-Robba' quarry.

\begin{tabular}{lccccc}
\hline & $\mathrm{Al}_{2} \mathrm{O}_{3} \%$ & $\mathrm{SiO}_{2} \%$ & $\mathrm{~K}_{2} \mathrm{O} \%$ & $\mathrm{TiO}_{2} \%$ & $\mathrm{Fe}_{2} \mathrm{O}_{3} \%$ \\
\hline Globigerina Limestone quarry samples $(n=23)$ & & & & & \\
Mean & 0.84 & 3.36 & 0.15 & 0.070 & 0.53 \\
Standard deviation & 0.26 & 0.95 & 0.05 & 0.02 & 0.14 \\
Minimum-maximum & $0.50-1.33$ & $1.9-5.5$ & $0.060-0.23$ & $0.040-0.12$ & $0.31-0.79$ \\
Confidence level (95.0\%) & 0.111 & 0.412 & 0.020 & 0.009 & 0.059 \\
'Soll' quarry samples $(n=12)$ & & & & & \\
Mean & 1.03 & 4.09 & 0.17 & 0.090 & 0.63 \\
Standard deviation & 0.22 & 0.68 & 0.03 & 0.02 & 0.11 \\
Minimum-maximum & $0.62-1.33$ & $3.1-5.5$ & $0.13-0.23$ & $0.070-0.12$ & $0.45-0.79$ \\
Confidence level (95.0\%) & 0.138 & 0.432 & 0.020 & 0.010 & 0.069 \\
'Franka' quarry samples $(n=11)$ & 0.65 & 2.55 & 0.12 & 0.050 & 0.42 \\
Mean & 0.10 & 0.36 & 0.05 & 0.01 & 0.07 \\
Standard deviation & $0.50-0.86$ & $1.9-3.3$ & $0.060-0.21$ & $0.040-0.070$ & $0.31-0.55$ \\
Minimum-maximum & 0.070 & 0.241 & 0.031 & 0.005 & 0.048 \\
Confidence level (95.0\%) & & & &
\end{tabular}

Table 4. Descriptive statistics and concentration limits for 'franka' and 'soll'.

\begin{tabular}{lccccc}
\hline & $\mathrm{Al}_{2} \mathrm{O}_{3} \%$ & $\mathrm{SiO}_{2} \%$ & $\mathrm{~K}_{2} \mathrm{O} \%$ & $\mathrm{TiO}_{2} \%$ & $\mathrm{Fe}_{2} \mathrm{O}_{3} \%$ \\
\hline 'Franka' samples from boreholes $(n=30)$ & & & & & \\
Mean & 0.62 & 2.35 & 0.090 & 0.040 & 0.34 \\
Standard deviation & 0.11 & 0.30 & 0.03 & 0.01 & 0.07 \\
Minimum-maximum & $0.40-0.83$ & $1.8-2.9$ & $0.040-0.15$ & $0.030-0.060$ & $0.26-0.54$ \\
Confidence level (95.0\%) & 0.042 & 0.111 & 0.010 & 0.003 & 0.026 \\
'Soll' samples from boreholes ( $(n=53)$ & & & & 0.11 & 0.86 \\
Mean & 1.53 & 5.05 & 0.25 & 0.03 & 0.27 \\
Standard deviation & 0.49 & 1.55 & 0.09 & $0.060-0.20$ & $0.47-1.64$ \\
Minimum-maximum & $0.78-2.90$ & $3.4-9.4$ & $0.13-0.47$ & 0.009 & 0.074 \\
Confidence level (95.0\%) & 0.134 & 0.427 & 0.024 & & \\
\hline
\end{tabular}

linkage. The four linkage methods showed that, for a high percentage $(96 \%)$ of the samples tested, the 'soll' and 'franka' classification of Lower Globigerina Limestone samples is not imposed by the techniques used, but exists and is uncovered by them.

PCA was also performed on these 23 samples (Fig. 5). Here it is seen that for the five variables used $\left(\mathrm{Al}_{2} \mathrm{O}_{3}\right.$, $\mathrm{SiO}_{2}, \mathrm{~K}_{2} \mathrm{O}, \mathrm{TiO}_{2}$ and $\mathrm{Fe}_{2} \mathrm{O}_{3}$ ), Factor (or Component) 1 is the most important and explains $88 \%$ of the variance. It can also be seen that the majority of the 'franka' samples tend to be grouped together, whereas the 'soll' samples (designated by the letter ' $\mathrm{S}$ ' in the symbol) also group together, separately from the 'franka' cluster.

For the 90 samples of Lower Globigerina Limestone obtained from the cores and having a similar aspect, it was not possible to determine by visual examination from which facies ('franka' or 'soll') the samples were obtained. Therefore, when carrying out cluster analysis on these samples, 'ideal types' or 'markers' were included in the datasets to suggest an interpretation for the clusters obtained (Milligan 1996). The markers (Fig. 6) used were the following quarry samples: W4 (a 'franka' marker); W16S (a 'soll' marker); and SOLL3 (a 'soll' sample obtained from the deepest layer of the quarry, and which is richer in
Si and Al than other 'soll' samples obtained from shallower layers). All four algorithms placed the three quarry markers in different groups. The smallest cluster, which always broke off first but which varied in size according to the linkage method used, invariably contained the marker obtained from the deepest quarry layer, and comprised samples obtained from the bottom of the cores. On the basis of the geochemical composition of the samples in this cluster, and on the 'marker' which fell within this group, this was called 'Si- and Al-rich soll'. On the other hand, the 'franka' marker always occurred in the cluster containing samples obtained from the top and middle parts of the cores, and never samples from the deepest layers. Figure 6 shows the clustering obtained using the complete linkage method. Samples marked 'S' derive from borehole B3, 'SS' from borehole B2, and 'SSS' from borehole B1. The numeral in the symbol increases with depth from ground level. This level is, however, not identical for all three boreholes.

The cluster groups obtained for the complete linkage algorithm are as follows:

Cluster 1 (no marker, from deep layers): SS32, SS33, S47, SS34, SS21, S18 


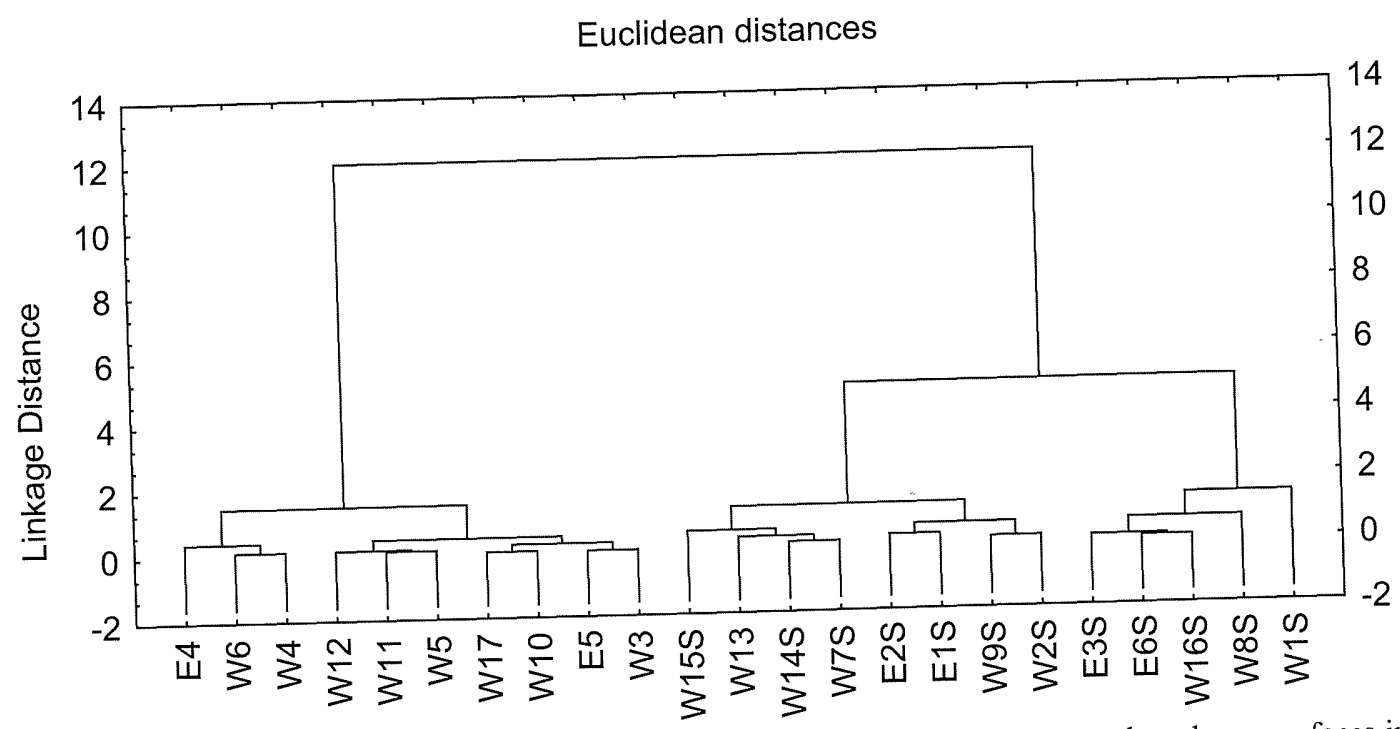

Fig. 3. Tree diagram (Ward's method) for 23 Lower Globigerina Limestone samples from weathered quarry faces in 'Tar-Robba' quarry (Mqabba). Note that the symbols with an 'S' denote 'soll' samples; samples labelled ' $E$ ' were obtained from the east face of the quarry; those labelled 'W', from the west face.

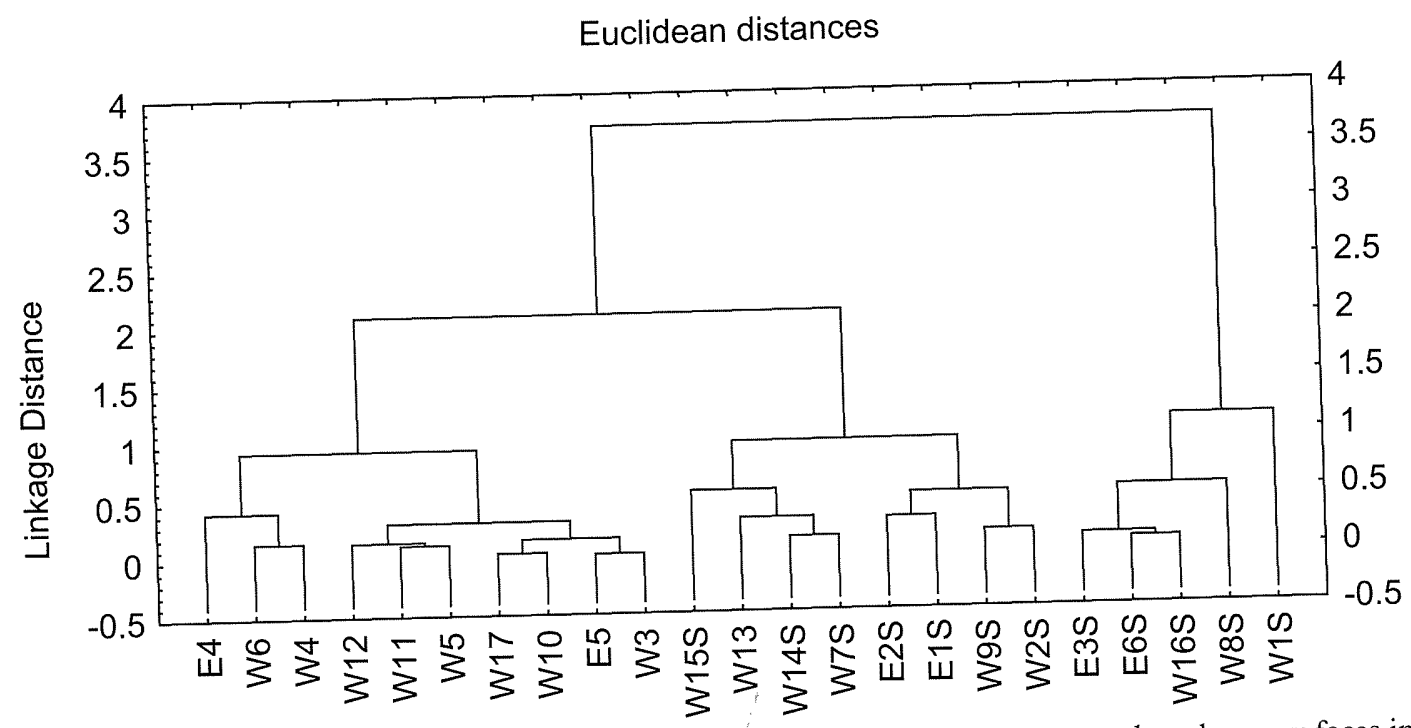

Fig. 4. Tree diagram (complete linkage) for 23 Lower Globigerina Limestone samples from weathered quarry faces in 'Tar-Robba' quarry (Mqabba) Note that the symbols with an 'S' denote 'soll' samples; samples labelled ' $E$ ' were obtained from the east face of the quarry; those labelled ' $W$ ', from the west face.

Cluster 2 (SOLL3 marker): S45, S44, SSS13, SS31, S46, S43, SSS10, S39, S49, S30

Cluster 3 (W16S marker): SS28, SS27, SS26, SS25, SS18, S42, SSS9, SSS5, S48, S33, S41, SSS12, SSS11, S40, SS30, SS24, SS23, S31, SS20, S16, SS29, S15

Cluster 4 (W4 marker): SSS2, SS13, S28, SS3, S12, S9, SS4, S10, S8, SS11, SS12, SS10, SS7, S27, S25, S24, S11, S26, SS9, SS6, SS8, SS5, SS2, SS1, S7

Cluster 5 (no marker): SSS4, SSS5, SSS3, SSS7, S38, S37, S36, S32, SS17, SS22, SS18, S34, S20, S22, S17, SS15, S23, S19, S14, SSS8, SSS1, S35, SS16, SS14, S29, S21, S13

Those samples which could not clearly be assigned the 'franka', 'soll' or 'Si- and Al-rich soll' label were called 'intermediate' samples. To assign the 'franka', 'soll' or 'intermediate' labels to all samples, the dendrograms obtained using the other algorithms were also taken into consideration. Types assigned depending on the results obtained by at least three clustering methods are given in Table 5.

Validation of the types thus assigned was then carried out by means of standard parametric MANOVA tests. Considering the 'soll' and 'Si- and Al-rich soll' samples as one group, and comparing them with the 'franka' samples, the p-level obtained is of 0.0001 , making the difference statistically highly significant.

PCA showed that for the five variables used here $\left(\mathrm{Al}_{2} \mathrm{O}_{3}, \mathrm{SiO}_{2}, \mathrm{~K}_{2} \mathrm{O}, \mathrm{TiO}_{2}\right.$ and $\left.\mathrm{Fe}_{2} \mathrm{O}_{3}\right)$ Factor 1 explains 


\section{Observations (axis F1 and F2: $94 \%$ )}

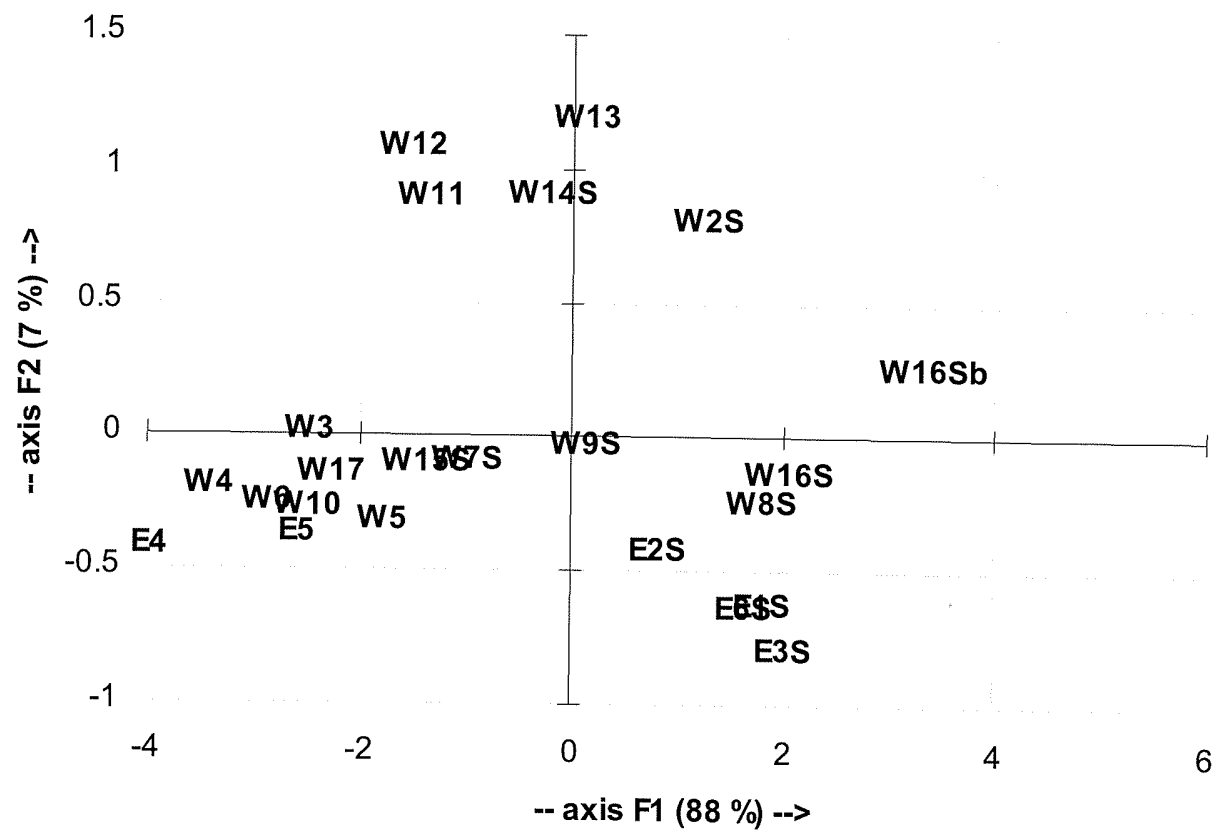

Fig. 5. Factor scores for 23 Lower Globigerina Limestone samples from weathered quarry faces in 'Tar-Robba' quarry (Mqabba). Note that the symbols with an 'S' denote 'soll' samples.

\section{Euclidean distances}

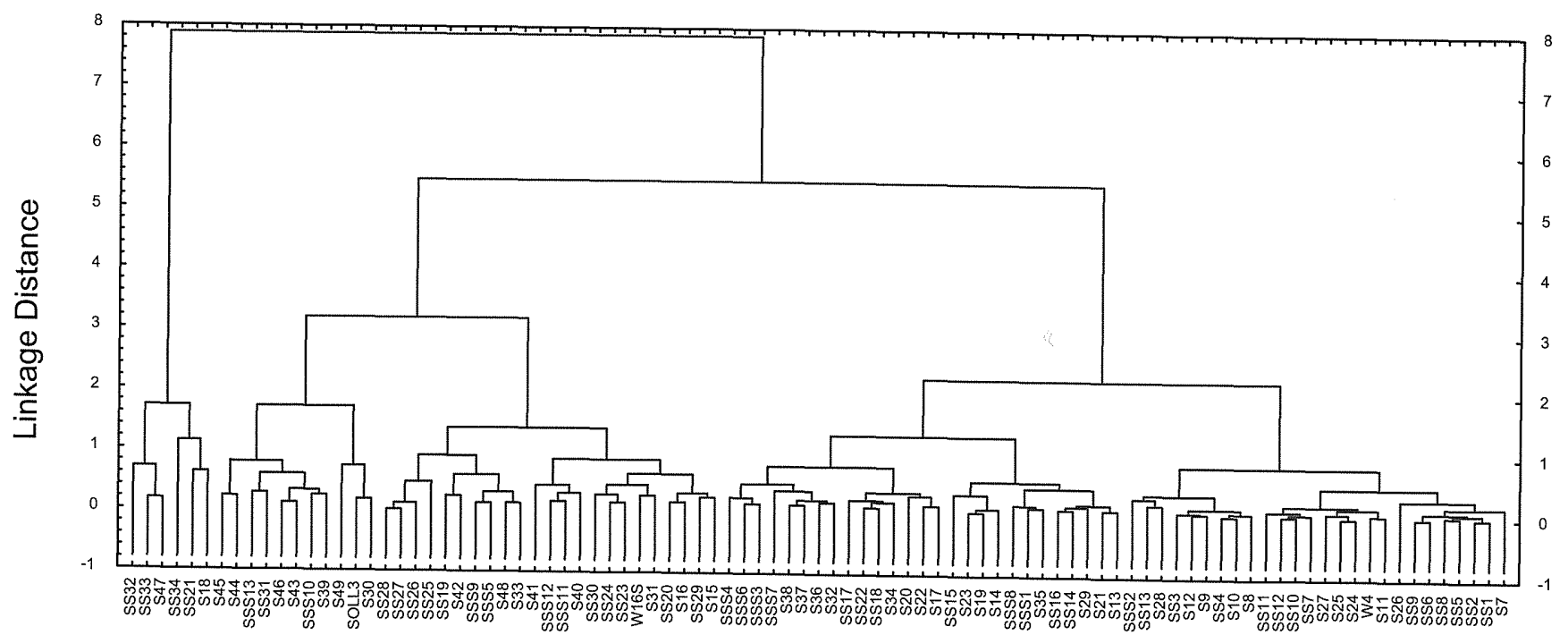

Fig. 6. Tree diagram (complete linkage) for 90 visually similar Lower Globigerina Limestone samples, with three quarry markers (W4, W16S, SOLL3). W4, 'franka' sample; W16S, 'soll' sample; SOLL3, Si- and Al-rich 'soll' sample.

$94 \%$ of the variance and Factor 2 accounts for $4 \%$ of the variance (Fig. 7). Here it can again be seen that the samples classified as 'franka' (F) by cluster analysis are all grouped together, whereas the 'soll' (S) and the 'Si- and Al-rich soll' (R)S samples formed a separate and distinct group, forming as it were a sub-group within the 'soll' samples. The 'intermediate' samples (IN) are located between the 'franka' and 'soll' groups. The 'markers' W4, W16S and SOLL3 can again be seen to appear in the 'correct' group of samples.
DA was then carried out to obtain an estimate of the misclassification of the method. Table 6 gives the $\mathrm{p}$-values for the four groups of samples, whereas Table 7 gives the misclassification table for the same four groups. Here it can be seen clearly that although some misclassification occurs between 'franka' and 'intermediate' samples, and, to a lesser extent between 'soll' and 'Si- and Al-rich' soll samples, there is no misclassification between 'franka' and either of the 'soll' groups. This is what makes the method useful when 
Table 5. Assignment of 'franka', 'intermediate', 'soll' and 'Si- and Al-rich soll' types to quarry samples

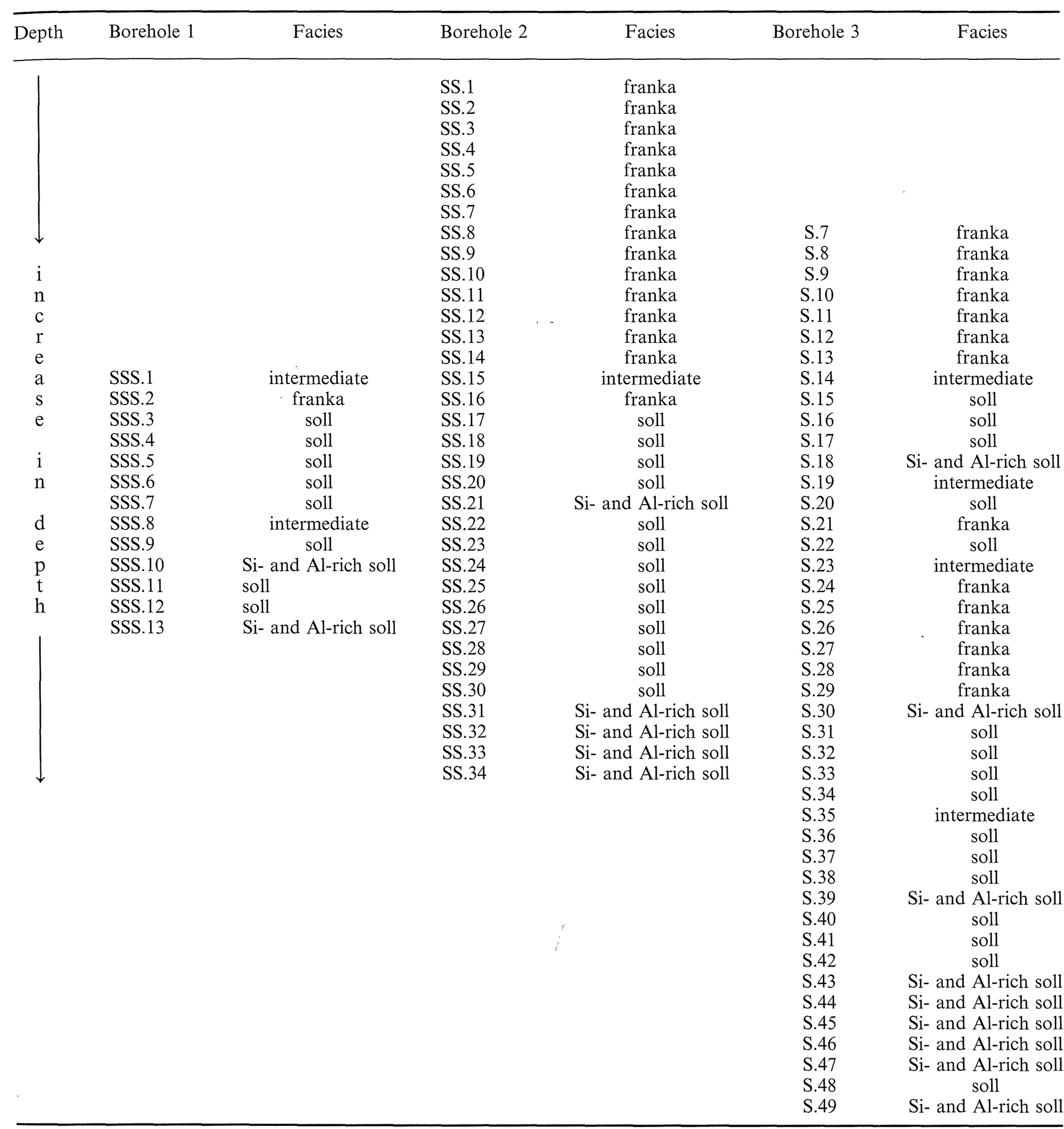

used to distinguish between 'good' and 'bad' stone types.

On the basis of core samples classified as 'franka' and 'soll' by cluster analysis, and as confirmed by PCA and DA, it was possible to establish numerical thresholds, i.e. concentration ranges within which fresh quarry samples could be designated as 'franka' or 'soll'. These limits, including errors for each oxide, are given in Table 8. The errors associated with the measurement of each major element in the analysis by XRF were calculated using certified reference carbonate standards (Table 9) as 'unknowns'. It was then assumed that errors established from CRM apply also to field samples. The concentration of each element in each standard was obtained from calibration curves and these values were then compared with the certified data, thus allowing the experimental errors for each element to be calculated. As a result of the inclusion of these errors in the data 


\section{Observations (axis F1 and F2: $98 \%$ )}

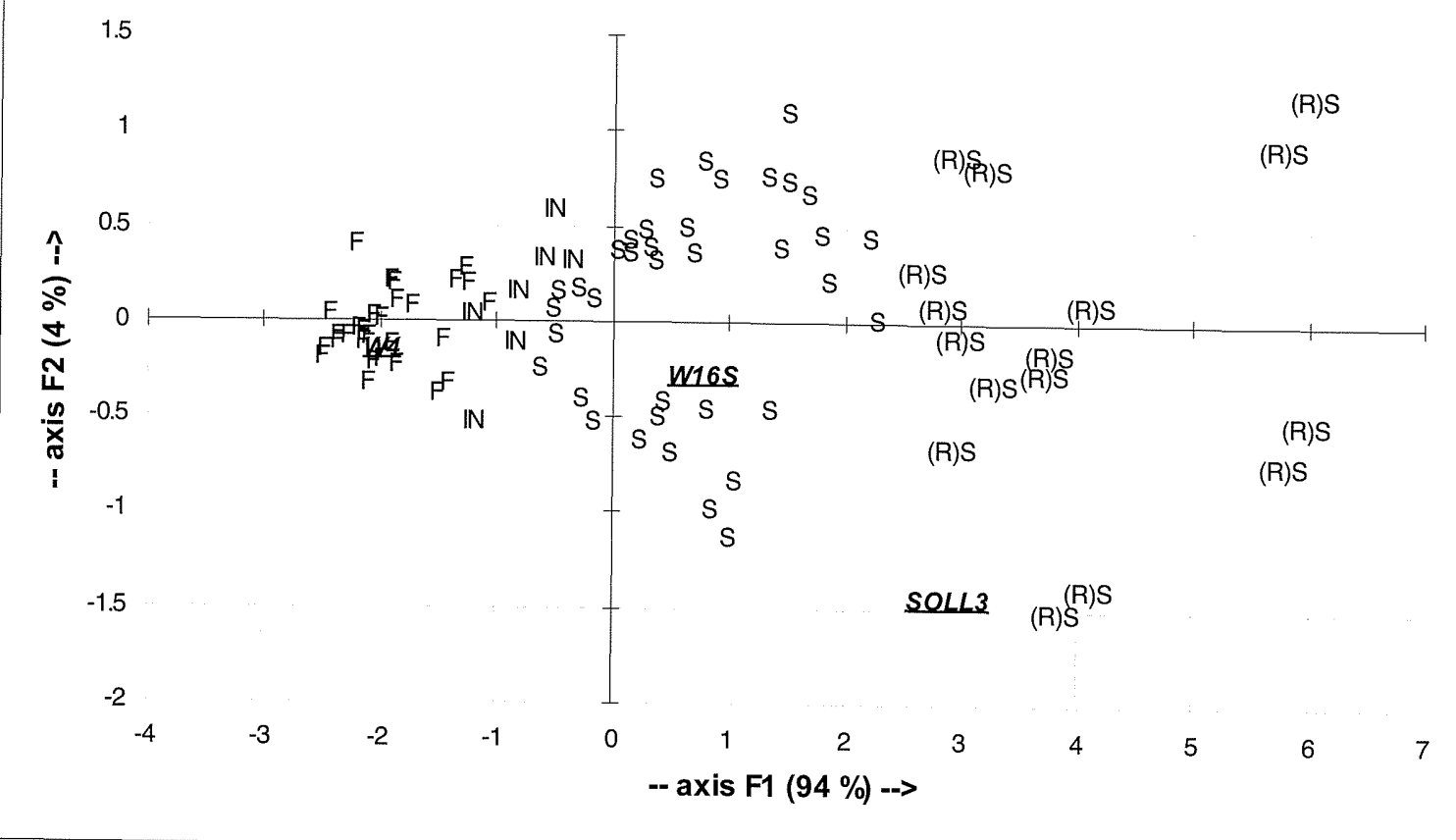

Fig. 7. Factor scores for 90 visually similar Lower Globigerina Limestone samples with three quarry markers (W4, W16S, SOLL3). F, 'franka'; IN, 'intermediate'; S, 'soll'; (R)S, 'Si- and Al-rich soll'; W4, 'franka' sample; W16S, 'soll' sample; SOLL3, Si- and Al-rich 'soll' sample.

Table 6. P-values of the Fisher's $F$ test for four groups of samples.

\begin{tabular}{lcccc}
\hline & Franka & Intermediate & Rich soll & Soll \\
\hline Franka & 1 & 0.151 & 0.000 & 0.000 \\
Intermediate & 0.151 & 1 & 0.000 & 0.008 \\
Rich soll & 0.000 & 0.000 & 1 & 0.000 \\
Soll & 0.000 & 0.008 & 0.000 & 1 \\
\hline
\end{tabular}

obtained for $\mathrm{Al}_{2} \mathrm{O}_{3}, \mathrm{SiO}_{2}, \mathrm{~K}_{2} \mathrm{O}$ and $\mathrm{Fe}_{2} \mathrm{O}_{3}$, there is some overlap in the established limits as follows: $\mathrm{Al}_{2} \mathrm{O}_{3}$ in the range $0.73 \%$ to $0.89 \% ; \mathrm{SiO}_{2}$ in the range $3.1 \%$ to $3.2 \%$; $\mathrm{K}_{2} \mathrm{O}$ in the range $0.12 \%$ to $0.17 \% ; \mathrm{Fe}_{2} \mathrm{O}_{3}$ in the range $0.45 \%$ to $0.56 \%$.
Therefore, these four oxides cannot be used, either singly or together, for samples having concentrations falling within these limits. For $\mathrm{TiO}_{2}$, on the other hand, there is no overlap and hence, theoretically, it can be used alone to identify a sample. However, given that even for $\mathrm{TiO}_{2}$, a concentration of exactly $0.060 \%$ would still leave a sample unclassified, and given that any analytical method is prone to error, it is recommended that all five variables be used for classification purposes. In fact, even then, as has already been seen, it is possible to have some samples that remain unassigned. Stratigraphically it is seen that, in all cores studied, the lowest layers always consist of 'soll' or 'Si- and Al-rich soll' (hereafter referred to by the general term 'soll'). It is also interesting to note that between the upper 'franka' layers

Table 7. Misclassification table for four sample groups, by discriminant analysis.

\begin{tabular}{|c|c|c|c|c|}
\hline & to Franka & to Intermediate & to Rich soll & to Soll \\
\hline \multirow[t]{2}{*}{ from Franka } & 25 & 4 & 0 & 0 \\
\hline & $28.09 \%$ & $4.49 \%$ & $0.00 \%$ & $0.00 \%$ \\
\hline from Intermediate & $\begin{array}{c}1 \\
112 \%\end{array}$ & $\begin{array}{c}6 \\
6740\end{array}$ & 0 & 0 \\
\hline \multirow[t]{2}{*}{ from Rich soll } & $\begin{array}{c}1.12 \% \\
0\end{array}$ & $\begin{array}{c}6.74 \% \\
0\end{array}$ & $\begin{array}{l}0.00 \% \\
16\end{array}$ & $\begin{array}{c}0.00 \% \\
1\end{array}$ \\
\hline & $0.00 \%$ & $0.00 \%$ & $17.98 \%$ & $1.12 \%$ \\
\hline from Soll & 0 & 7 & 1 & 28 \\
\hline \multirow[t]{2}{*}{ Sum } & $\begin{array}{l}0.00 \% \\
26 \\
20210\end{array}$ & $\begin{array}{c}7.87 \% \\
17\end{array}$ & $\begin{array}{l}1.12 \% \\
17\end{array}$ & $\begin{array}{c}31.46 \% \\
29\end{array}$ \\
\hline & $29.21 \%$ & $19.10 \%$ & $19.10 \%$ & $32.58 \%$ \\
\hline
\end{tabular}

Apparent error rate: $15.73 \%$ 
Table 8. Established geochemical limits, including errors, for 'franka' and 'soll' facies.

\begin{tabular}{lccccc}
\hline & $\mathrm{Al}_{2} \mathrm{O}_{3}$ & $\mathrm{SiO}_{2}$ & $\mathrm{~K}_{2} \mathrm{O}$ & $\mathrm{TiO}_{2}$ & $\mathrm{Fe}_{2} \mathrm{O}_{3}$ \\
\hline & & & & \\
'Franka' & $<0.83 \% \pm 0.06 \%$ & $<2.9 \% \pm 0.3 \%$ & $<0.15 \% \pm 0.02 \%$ & $<0.060 \% \pm 0.002 \%$ & $<0.54 \% \pm 0.02 \%$ \\
'Soll' & $>0.78 \% \pm 0.05 \%$ & $>3.4 \% \pm 0.3 \%$ & $>0.13 \% \pm 0.01 \%$ & $>0.060 \% \pm 0.002 \%$ & $>0.47 \% \pm 0.02 \%$ \\
\hline
\end{tabular}

Table 9. Sample name and source of certified reference standards used for calibration curves.

\begin{tabular}{lll}
\hline Standard & \multicolumn{1}{c}{ Sample name } & \multicolumn{1}{c}{ Source } \\
\hline 400 & dolomite - Woodville, Ohio & \\
JLs-1 & $\begin{array}{l}\text { Garo limestone (Triassic), Kamiiso-cho, Kaniisogun, } \\
\text { Hokkaido }\end{array}$ & $\begin{array}{l}\text { GFS Chemicals, USA } \\
\text { Geological Survey of Japan }\end{array}$ \\
JDo-1 & Kuzuu dolomite (Permian), Kuzuu-machi, Tochigi & Geological Survey of Japan \\
& Prefecture & British Chemical Standards, UK \\
393 & limestone - Peak District, Derbyshire, UK & Universite de Liege, Belgium \\
CCH1 & Crinoidic limestone of Tournaisian age (Tn3b) & GFS Chemicals, USA \\
404 & limestone-dolomite blend & National Institute of Standards and Technology, USA \\
$88 \mathrm{a}$ & dolomitic limestone & GFS Chemicals, USA \\
401 & limestone - Marble Cliff, Ohio & GFS Chemicals, USA \\
402 & limestone - Spore, Ohio & GFS Chemicals, USA \\
417 & limestone-dolomite blend & Dillinger Laboratory, Germany \\
3507 & limestone & National Institute of Standards and Technology, USA \\
$1 \mathrm{~b}$ & argillaceous limestone & National Institute of Standards and Technology, USA \\
$1 \mathrm{c}$ & argillaceous limestone & Zentrales Geologisches Institut, Berlin, Germany \\
KH & limestone & Institute of Geophysical and Geochemical Prospecting, \\
GSR6 & limestone with small amounts of dolomite & China \\
\hline
\end{tabular}

Table 10. Summary of results for main minerals and insoluble residues in 'franka' and 'soll' facies.

\begin{tabular}{lcccc}
\hline & Quartz & K-Feldspars & Phyllosilicates & Insoluble residue \\
\hline 'Franka' & & & \\
range (\%) & trace to 2 & $0-1$ & $1-3$ & $1-3$ \\
mean (\%) & & 1.4 & 1.8 \\
coefficient of variation (\%) & & 40.3 & 42.9 \\
'Soll' & trace to 8 & $0-1$ & $1-12$ & $3-14$ \\
range (\%) & & 4.4 & 6.6 \\
mean (\%) & & 49.8 & 39.6 \\
coefficient of variation $(\%)$ & & & & \\
\hline
\end{tabular}

and the lower 'soll' layers, bands of 'intermediate', 'franka' and 'soll' types occur but in no specific order. These vary in thickness from $1 \mathrm{~m}$ to $6 \mathrm{~m}$.

Considering the results of the XRD analyses of whole powders and data pertaining to the acid-insoluble residues, the following observations can be made (Table 10). For the phyllosilicates, there is a distinct difference between the means obtained for 'franka' and 'soll' samples. The clay mineral content cannot, however, be utilized to distinguish between 'franka' and 'soll' samples, as there is an overlap in the range $1-3 \%$. For the insoluble residues, there is again a clear difference between the means for the two types of Lower Globigerina Limestone. Once again, however, there is an overlap in the ranges (for $11 \%$ of the samples), occurring at the $3 \%$ concentration. 'Soll' is also richer than 'franka' in quartz, as seen by XRD and confirmed by observations in thin section. This is a direct confirmation of the higher quantities of $\mathrm{SiO}_{2}$ detected by XRF in 'soll' samples. There are also more glauconitic granules in 'soll', as confirmed by microscopic observation. However, thin section observations were not found to be useful in distinguishing 'franka' from 'soll' samples, due to the erratic distribution of the non-carbonate minerals. However, the higher concentrations of these minerals are translated, as expected, into higher insoluble residues for 'soll' compared to 'franka'. This parameter may, in fact, also be used as a rough indicator to distinguish between 'franka' and 'soll' samples, although in view of the overlap at the $3 \%$ concentration, samples having this fraction of insoluble residue cannot be classified. Besides, this parameter has been obtained indirectly 
from the results of calcimetric analysis. This has an error of $4 \%$. Therefore, the concentration ranges for $\mathrm{CaCO}_{3}$ are $93 \pm 4-99 \pm 4 \%$ for 'franka' and $85 \pm 4-97 \pm 4 \%$ for 'soll'.

\section{Conclusion}

A method has been developed based exclusively on geochemical data, capable of distinguishing between durable and less durable limestone specimens that are otherwise identical in visual aspect. Differentiation between these two types of material has significant importance for the building industry, especially in Malta where this industry relies heavily on the use of limestone blocks for general construction purposes. The method can also provide useful information in connection with replacement of deteriorated stones in the restoration of old buildings and monuments. Strong conclusions can be drawn on the basis of the combined results from $\mathrm{Si}$, $\mathrm{Ti}, \mathrm{Al}, \mathrm{K}$ and $\mathrm{Fe}$ determination. It is notable that data based on acid insoluble residues can also provide sufficient discrimination for most 'soll' limestone. The error associated with acid insoluble residues as derived from calcimetry is high: we are currently investigating whether direct gravimetry might afford a more accurate method of identification.

Acknowledgements. The authors would like to thank Anton Buhagiar of the University of Malta for his help with the statistics. The authors would also like to acknowledge the active and long-term participation of the late S. Vannucci, Professor of Applied Geology at the Department of Earth Sciences, University of Florence, Italy, in the research project that resulted in this publication. This paper is dedicated to his memory.

\section{References}

BAXTER, M.J. \& JACKSON, C.M. 2001. Variable selection in artefact compositional studies. Archaeometry, 43(2), 253-268.

Building Research Establishment. 1999. Combe Down, Bath Stone. Technical Data Sheet, The BRE/British Stone Stone List. Internet site: http://projects.bre.co.uk/ConDiv/ stonelist/combedown.html.

Building Research Establishment Digest 1983. The selection of natural building stone. Building Research Establishment, Department of the Environment, UK.

CASSAR, J. 1999. Geochemical and mineralogical characterisation of the Lower Globigerina Limestone of the Maltese islands with special reference to the 'soll' facies. $\mathrm{PhD}$ thesis. University of Malta.

CASSAR, J. 2002. Deterioration of the Globigerina Limestone of the Maltese Islands. In: Siegesmund, S., Vollbrecht,
A. \& Weiss, T. (eds) Natural Stone, Weathering Phenomena, Conservation Strategies and Case Studies. Geological Society, London, Special Publications, 205, 25-41.

Davis, J.C. 1986. Statistics and data analysis in geology (2nd edn). John Wiley, New York.

Fitzner, B., Heinrichs, K. \& Volker, M. 1996. Model for salt weathering at Maltese Globigerina Limestones. In: ZEzzA, F. (ed.) Origin, Mechanisms and Effects of Salt on Degradation of Monuments in Marine and Continental Environments. Proceedings, European Commission Research Workshop on Protection and Conservation of the European Cultural Heritage, Bari, Italy. Research Report, 4, 331-344.

Fowlkes, E.B., Gnanadesikan, R. \& Kettering, J.R. 1988. Variable selection in clustering. Journal of Classification, 5, 205-288.

Galea, R.V. 1915. Geology of the Maltese archipelago. Malta and Gibraltar Illustrated. Macmillan, London, 173-182.

GLASCOCK, M.D. 1992. Characterization of archaeological ceramics at MURR by neutron activation analysis and multivariate statistics. In: NeFF, H. (ed.) Chemical characterization of ceramic pastes in archaeology. Prehistory Press, Madison, W1, 11-26.

Harbottle, G. 1976. Activation analysis in archaeology. Radiochemistry, 3, 33-72.

Harrison, P. 2001. Harmonised European StandardsNatural Stone. Internet site: http://www.szerelmey.com/ techadvice/tech2.htm.

Honeyborne, D.B. 1998. The selection of stone for repairs. In: Ashurst, J. \& Dimes, F.G. (eds) Conservation of Building and Decorative Stone. Butterworth-Heinemann, Oxford, 71-77.

KrZANOWski, W.J. 1988. Principles of multivariate analysis. Clarendon Press, Oxford.

Milligan, G.W. 1996. Clustering validation: results and implications for applied analyses. In: Arabie, P., Hubert, L.J. \& De Soete, G. (eds) Clustering and Classification. World Scientific Publishing Co Pte Ltd, Singapore, 341-375.

Murray, J. 1890. The Maltese islands, with special reference to their geological structure. Scottish Geographical Magazine, 6, 449-488.

Oil Exploration Directorate 1993. Geological map of the Maltese islands. Office of the Prime Minister, Malta.

Pedley, H.M. 1978. A new lithostratigraphical and palaeoenvironmental interpretation for the Coralline Limestone formations (Miocene) of the Maltese islands. Overseas Geology and Mineral Resources, 54. Institute of Geological Sciences, London.

Pollard, A.M. 1986. Multivariate methods of data analysis. In: Jones, R.E. (ed.) Greek and Cypriot pottery: a review of scientific studies. British School at Athens Fitch Laboratory Occasional Paper, 1.

Sneath, P.H.A. \& Sokal, R.R. 1973. Numerical Taxonomy: the principles and practice of numerical classification. W. H. Freeman, San Francisco.

Swan, A.R.H. \& SANDILANDS, M. 1995. Introduction to geological data analysis. Blackwell Science Ltd, Oxford.

Vella, A.J., Testa, S. \& Zammit, C. 1997. Geochemistry of the Soll facies of the Lower Globigerina Limestone formation, Malta. Xjenza (Malta Chamber of Scientists), 2(1), 27-33. 


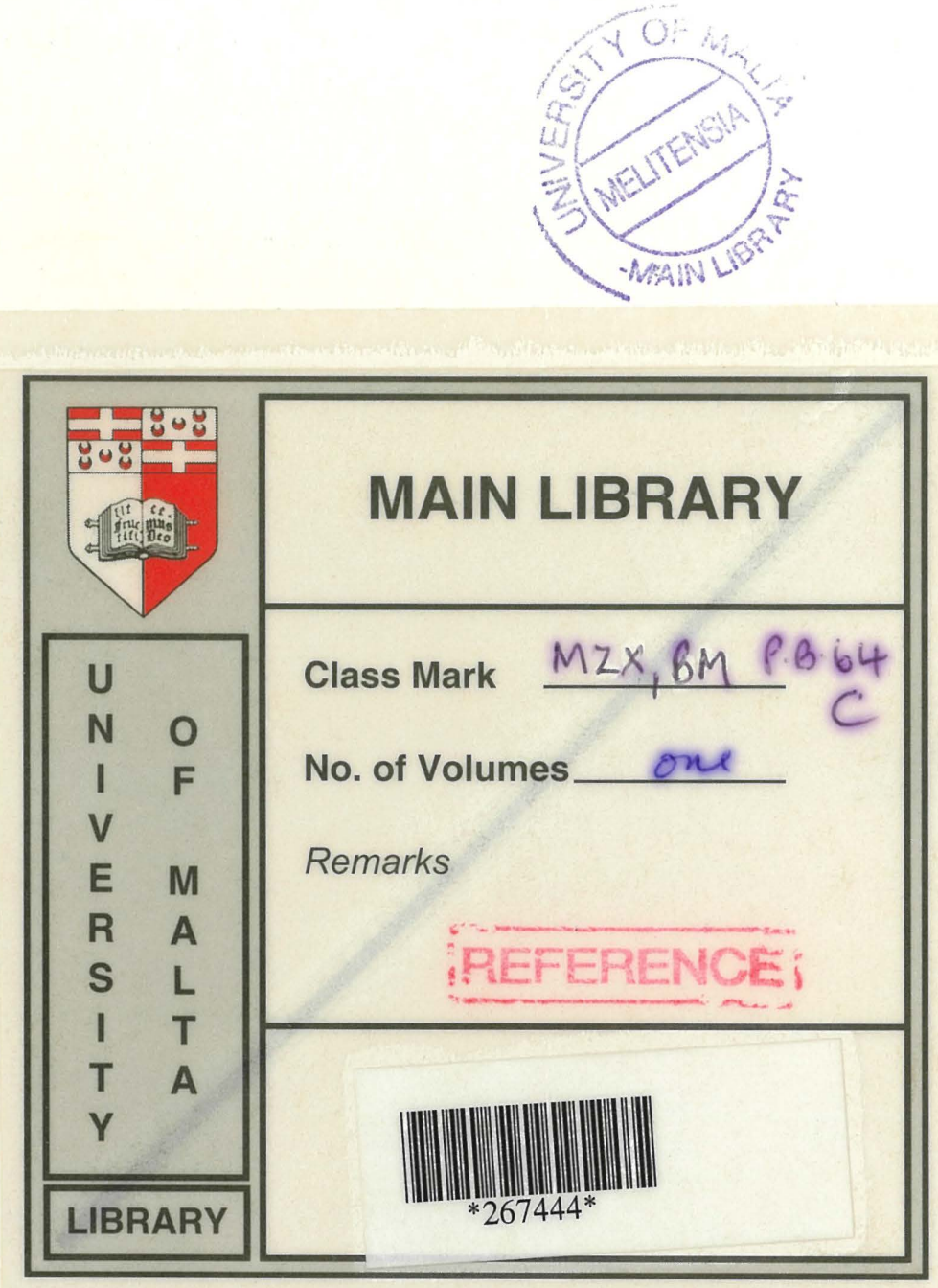


M8. X5M

80.9 .9 